\section{Macrodactyly of Toes in a Developing Community}

\section{Wilson Onuigbo ${ }^{1 *}$ and Frank Akpuaka ${ }^{2}$}

${ }^{1}$ Department of Pathology, Medical Foundation and Clinic, Nsukka Lane, Enugu, Nigeria

${ }^{2}$ Department of Plastic Surgery, National Orthopaedic Hospital, Enugu, Nigeria

\begin{abstract}
The study of macrodactyly, which is defined as phalangeal enlargement of one or more toes usually apparent from birth, is important. The senior author (WO) is interested in the Reprint Request (RR) on which he has published 2 articles on this subject. Therefore, the findings in them are compared with cases seen among the Ibos or Igbos who constitute one of the major ethnic groups domiciled mostly in the South-Eastern region of Nigeria. Authors deal in the article with data which are in line with those published materials.

Keywords: Epidemiology; Health education; Igbos; Macrodactyly; Toes
\end{abstract}

\section{Introduction}

The Requested Reprint (RR) was not long ago a major form of scientific information. Incidentally, Swales [1], Editor of English for Specific Purposes, wrote concerning me thus: "the only active researcher that I have traced in the RR area." In fact, my research revealed that RR is a "tracer tool" in documentation [2]. Therefore, what my mini-Library reveal concerning macrodactyly?

Two reprints surfaced. Firstly, there was a case report of a 6-yearold Saudi girl whose fingers and toes were involved [3]. Secondly, not only 5 personal cases but also 40 from the literature were published [4]. Accordingly, I followed the tip of a UK group that a histopathology data pool suffices in epidemiological analysis [5]. I established such a pool among my own people, the Igbos [6], who constitute a major Ethnic Group in the South-Eastern Region of Nigeria. The present paper describes my experience in fishing for the local cases of macrodactyly.

\section{Materials and Methods}

From 1970 to 2000, when I was the pioneer pathologist in the Regional Pathology Laboratory situated at Enugu, Nigeria, I kept

${ }^{\star}$ Corresponding author: Wilson Onuigbo, Department of Pathology, Medical Foundation and Clinic, Nsukka Lane, Enugu, Nigeria, Tel: +234 8037208680; E-mail: wilson.onuigbo@gmail.com

Citation: Onuigbo W, Akpuaka F (2016) Macrodactyly of Toes in a Developing Community. J Cytol Tissue Biol 3: 010.

Received: May 09, 2016; Accepted: September 02, 2016; Published: September 15,2016 careful records of cases submitted by several surgeons with the proviso that the specimens must be accompanied by well documented clinical data. Their analysis is the subject of this paper. Figure 1 is illustrative of this picturesque condition.

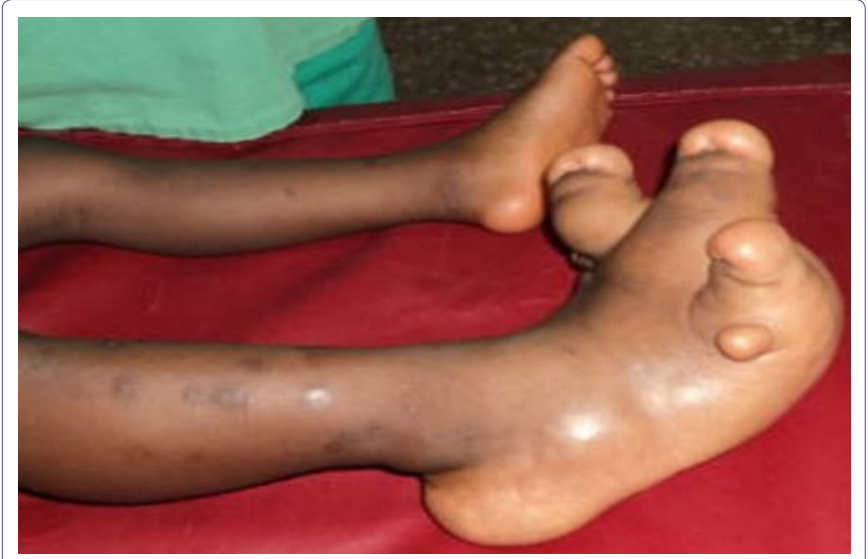

Figure 1: Macrodactyly in right foot compared with the left.

\section{Results}

These have been tabulated here under as follows (Table 1):

\begin{tabular}{|c|c|c|c|c|c|}
\hline S/N & Lab No & Initials & Age & Sex & Toe \\
\hline 1 & B 610/76 & MO & 1 & M & All \\
\hline 2 & HU 436/83 & EE & 14 & M & Little \\
\hline 3 & H 302/84 & EG & 8 & F & Big \\
\hline 4 & UH 2816/87 & EC & 1 & M & 1st, 2nd \\
\hline 5 & H 181/90 & Al & 20 & F & Little \\
\hline 6 & 9209127 & AU & 9 & M & All \\
\hline 7 & 921117 & NH & 25 & F & Big \\
\hline 8 & 9312129 & OJ & 13 & F & Big \\
\hline 9 & 9402196 & OA & 3 & F & 2nd - 4th \\
\hline 10 & H 21/96 & OC & 11 & M & 3rd - 5th \\
\hline
\end{tabular}

\section{Discussion}

This is done here with due reference to comparison with the 45 published RR cases [3]. All of them exhibited lipomatous constituents. Both male and female patients were equal in the ratio of 5 each. Unlike the published cohort with "noted soon after birth," the local age ranged from a year to 25 years, averaging almost 10 years. This must be due to the state of underdevelopment of the community. It is necessarily an indication of the need for public health education. Elsewhere, it was shown how the community may benefit in general with such education in the fields of albinism [7,8]. Now, sunlight exposure causes skin cancer. Therefore, it is argued that statutory indoor employment is mandatory for these unfortunate citizens.

\section{Acknowledgment}

We are indebted to Mr. Edward Chukwukeje for the photograph. 
There is no Conflict of Interest.

\section{References}

1. Swales J (1986) ESP in the big world of reprint requests. English for Specific Purposes 5: 81-85.

2. Onuigbo WIB (1985) Reprint requests - a tool for documentation. Int For Inform Document 10: 7-9.

3. Mahdi AH, Patel PJ, Hawas NE (1987) Macrodystrophia lipomatosa: A case report. Ann Saudi Med 7: 248-249.

4. Yaghmai I, McKowne F, Alizadeh A (1976) Macrodactylia fibrolipomatosis. South Med J 69: 1565-1568.
5. Macartney JC, Rollaston TP, Codling BW (1980) Use of a histopathology data pool for epidemiological analysis. J Clin Pathol 33: 351-355.

6. Basden GT (1966) Niger Ibos: A Description of the Primitive Life, Customs, and Animistic Beliefs, \&c., of the lbo People of Nigeria by One Who, for Thirty-five Years, Enjoyed the Privilege of Their Intimate Confidence and Friendship. Barnes \& Noble Publishers, New York, USA.

7. Onuigbo W (2015) No Albino Should Suffer From Extensive Skin Cancer Let Alone Die There-From. J Cancer Prev Curr Res 2: 1-2.

8. Onuigbo W (2015) The Influence Of Pott's Irritation Theory Of Occupational Cancer During the $19^{\text {th }}$ Century: A Review with Hypothesis on Albinism Sunlight Induced Cancer. J Cancer Prev Curr Res 2: 1-3. 